\title{
A current source inverter-based unified power quality conditioner for mitigation of voltage and current harmonics
}

\section{Abdul Hamid Bhat* and Anupam Kumar}

Electrical Engineering Department, NIT Srinagar,

Kashmir, India

Email: bhatdee@nitsri.net

Email: kanupam310@gmail.com

*Corresponding author

\section{Arfat Firdous}

Department of Physics,

Islamia College of Science and Commerce,

Srinagar, Kashmir, India

Email: arfat2phy@gmail.com

\begin{abstract}
This paper presents an analysis of current source inverter (CSI)-based unified power quality conditioner (UPQC) to improve the electric power quality at distribution levels. In recent years unified power quality conditioner (UPQC) is being used as a universal active power conditioning device to mitigate both voltage as well as current harmonics in a polluted power system network. Fabrication of UPQC is done implying both current source and voltage source inverter. Current source UPQC has unique advantages over generalised voltage source-based UPQC. Reference and switching signals are derived using a simple PI controller and robust hysteresis band PWM technique respectively. The resultant compensation system eliminates voltage as well as current harmonics with good dynamic response. Extensive simulation results using MATLAB/Simulink and SimPowerSystems software for R-L load connected through an uncontrolled bridge rectifier is presented for performance evaluation.
\end{abstract}

Keywords: power quality conditioner; current source inverter; CSI; VSI; current harmonics; voltage harmonics; hysteresis controller; series active filter; shunt active filter; unified power quality conditioner; UPQC.

Reference to this paper should be made as follows: Bhat, A.H., Kumar, A. and Firdous, A. (2018) 'A current source inverter-based unified power quality conditioner for mitigation of voltage and current harmonics', Int. J. Industrial Electronics and Drives, Vol. 4, No. 1, pp.1-15.

Biographical notes: Abdul Hamid Bhat received his BTech in Electrical Engineering from NIT Srinagar and MTech and $\mathrm{PhD}$ in Electrical Engineering from IIT Roorkee (India). He is presently working as an Associate Professor in Electrical Engineering Department of NIT Srinagar, Kashmir (India).

Anupam Kumar received his BTech in Electrical and Electronics Engineering from Lovely Professional University and MTech in Electrical Power and Energy Systems from NIT Srinagar. $\mathrm{He}$ is presently pursuing his $\mathrm{PhD}$ degree programme at NIT Srinagar.

Arfat Firdous received his PhD in Physics from NIT Srinagar. He is presently working as an Assistant Professor in Department of Physics, Islamia College of Science and Commerce, Srinagar, Kashmir (India).

\section{Introduction}

The word 'power quality' is the most important facets of any power delivery system. Poor power quality affects electricity consumers in many ways. The lack of quality power can cause severe damage to sensitive equipments can result in increase in power losses, and interference with communication lines. The widespread use of power electronics equipment generates harmonics in voltages and currents and produces a significant impact on quality of electric power supply. Therefore, it is very important to maintain a high standard of power quality (Bollen, 2000; 
Dugan et al., 2004, 2006; IEEE Std. 1159-1995; Antonio, 2007).

One of the best solutions for mitigation of the major power quality problems is active power filtering (Aredes, 1995). These are a good solution for problems of power quality. A large number of configurations such as series, shunt, hybrid (a combination of shunt and passive filters) have been introduced and improved (Horn et al., 1996; Balbo and Malesani, 1993; Prabhu, 2014; Syamnaresh and Rajesh, 2012). The unified power quality conditioner (UPQC) (Hugh and Sabahi, 2016) has been widely studied by many researchers as an ultimate device to improve power quality (Chen et al., 2000; Akagi and Fujita, 1995; Singh et al., 1999; Fujita and Akagi, 1998; Khadkikar et al., 2004; Venkatesh and Elano, 2013; Valsala and Padma Suresh, 2013).UPQC can be designed as VSI-based, CSI-based and hybrid in design (Venkatesh and Elano, 2013).UPQC provides a relevant, weighty and flexible alternative to mitigate both voltage as well as current disturbances simultaneously by a single unit. It generally consists of two bi-directional converters connected back to back through an energy storage device (Vaidirajacharya et al., 2007). VSI-based UPQC was in use due to its cost effectiveness, compact size and flexibility to extend multilevel converter topology. Principle of operation, various configurations, and control of VSI- based UPQC is presented in depth in references (Chen et al., 2000; Akagi and Fujita, 1995; Singh et al., 1999; Fujita and Akagi, 1998; Akagi et al., 2007).

As new IGBTs with reverse blocking capability have become available, there is an increment in the use of current source active filters due to its inbuilt short circuit protection capability, higher efficiency at low power loads, effective filtering of harmonics and simple open loop current control. Control aspect of current source active power filter and various configurations have been discussed by many researchers (Hayashi et al., 1997; Salo and Tuusa, 2005). Performance of CSI-based UPQC is presented by Graovac et al. (2001). A comparison of current and voltage source shunt active power filters is presented in Salo and Tuusa (2005), Benchaita et al. (1999), Yunus and Bass (1996), Khadkika et al. (2004) and Eldin Bahr et al. (2012).

This paper presents a comprehensive analysis of current source inverter (CSI)-based UPQC using a simple PI controller for derivation of reference signals. These reference signals are then compared in a robust hysteresis controller for generation of switching signals. The CSI-based UPQC exhibits excellent performance for current as well as voltage harmonic mitigation.

\section{System modelling and description}

The equivalent circuit diagram of UPQC is shown in Figure $1 V_{s}$ is the supply voltage, $V_{c}$, and $i_{c}$ are the series compensation voltage, shunt compensation current and $V_{L}$ and $i_{L}$ are the load voltage and load current respectively.
Figure 1 Schematic diagram of UPQC

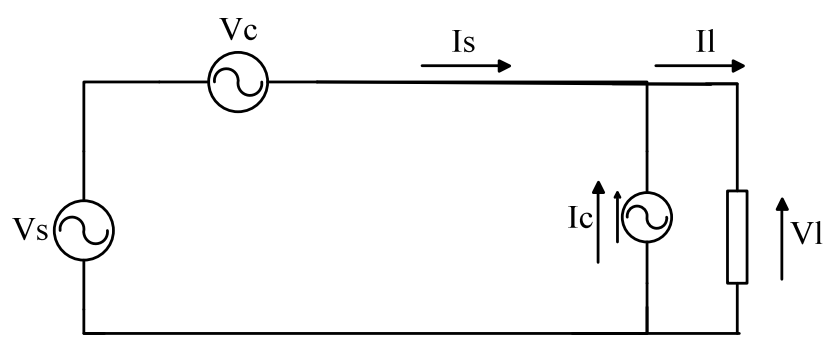

The source voltage may contain positive, negative and zero sequence components as well as harmonic components. The per phase voltage of the system can be expressed as:

$$
V_{s a}=V_{1 p a}+V_{1 n a}+V_{10 a}+\sum_{k=2}^{\infty} V_{k a} \sin \left(k \omega t+\theta_{k a}\right)
$$

Here $V_{s a}$ is per phase voltage.

$V_{1 p a}$ is fundamental frequency positive sequence component.

$V_{1 n a}, V_{10 a}$ are negative and zero sequence components respectively.

The harmonic content in the voltage is represented by the last term of equation. For the load voltage to perfectly sinusoidal and balanced, the series filter should produce a voltage equal to

$$
V_{a h}=V_{1 n a}+V_{10 a}+\sum_{k=2}^{\infty} V_{k a} \sin \left(k \omega t+\theta_{k a}\right)
$$

Functions of the shunt active filter are to provide compensation of the load harmonic current, load reactive power demand and also to maintain DC link current constant.

The per phase load current of shunt active filter is expressed as:

$$
\begin{aligned}
i_{a l}= & i_{a 1 p} \cos \left(\omega t-\theta_{1}\right)+i_{a 1 n}+\sum_{k=2}^{\infty} i_{a l k} \\
i_{a l}= & i_{a 1 p} \cos (\omega t) \cos \left(\theta_{1}\right) \\
& \quad+i_{a 1 p} \sin (\omega t) \sin \left(\theta_{1}\right)+i_{a 1 n}+\sum_{k=2}^{\infty} i_{a l k}
\end{aligned}
$$

For compensation of harmonic current and meeting the reactive power demand the shunt active filter should produce a current of

$$
i_{a h}=i_{a 1 p} \sin (\omega t) \sin \left(\theta_{1}\right)+i_{a 1 n}+\sum_{k=2}^{\infty} i_{a l k}
$$

Therefore source current is

$$
i_{a s}=i_{a l}-i_{a h}=i_{a 1 p} \cos (\omega t) \cos \left(\theta_{1}\right)
$$

Thus the source current will be free from harmonics and will be in phase with source voltage. 


\section{Control algorithm}

The schematic diagram of CSI-based unified power quality conditioner is shown in Figure 2. It consists of series and shunt filter connected by a common DC inductor.

\subsection{Series filter controller}

Series filter is controlled by hysteresis band voltage control in CSI-based Unified Power Quality Conditioner. The series active filter acts as controlled voltage source; it imposes high impedance for the harmonic currents and blocks their flow from both load to source and source to load directions. The source voltage may contain zero, negative sequence as well as harmonic component, which need to be eliminated by series compensator, in order for the load voltage to perfectly sinusoidal and balanced, thus the series filter should produce a voltage given by equation (2). A PLL-based unit vector templates is multiplied with a constant equal to peak amplitude of fundamental input voltage to obtain reference load voltages. Unit vector templates for different phases are obtained with proper phase delay as follows:

$$
U_{a}=\sin (\omega t)
$$

$$
\begin{aligned}
& U_{b}=\sin \left(\omega t-120^{\circ}\right) \\
& U_{c}=\sin \left(\omega t+120^{\circ}\right)
\end{aligned}
$$

The compensation signals are generated as given below:

$$
\begin{aligned}
& V_{f a}^{*}=V_{s a}-V_{m} \cdot U_{a} \\
& V_{f b}^{*}=V_{s b}-V_{m} \cdot U_{b} \\
& V_{f c}^{*}=V_{s c}-V_{m} \cdot U_{c}
\end{aligned}
$$

where $V_{s a}, V_{s b}, V_{s c}$ are phase voltage of three phases respectively.

$U_{a}, U_{b}, U_{c}$ are unit vector templates for three phases respectively.

$V_{m}$ is the constant equal to peak amplitude of fundamental input voltage.

The compensation signals are then compared with actual signals at the terminals of series active filter, the error is then given to hysteresis controller and the required gating signals for series filter is generated.

The control block diagram of series filter is as shown in Figure 3.

Figure 2 Schematic diagram of CSI-based unified power quality conditioner

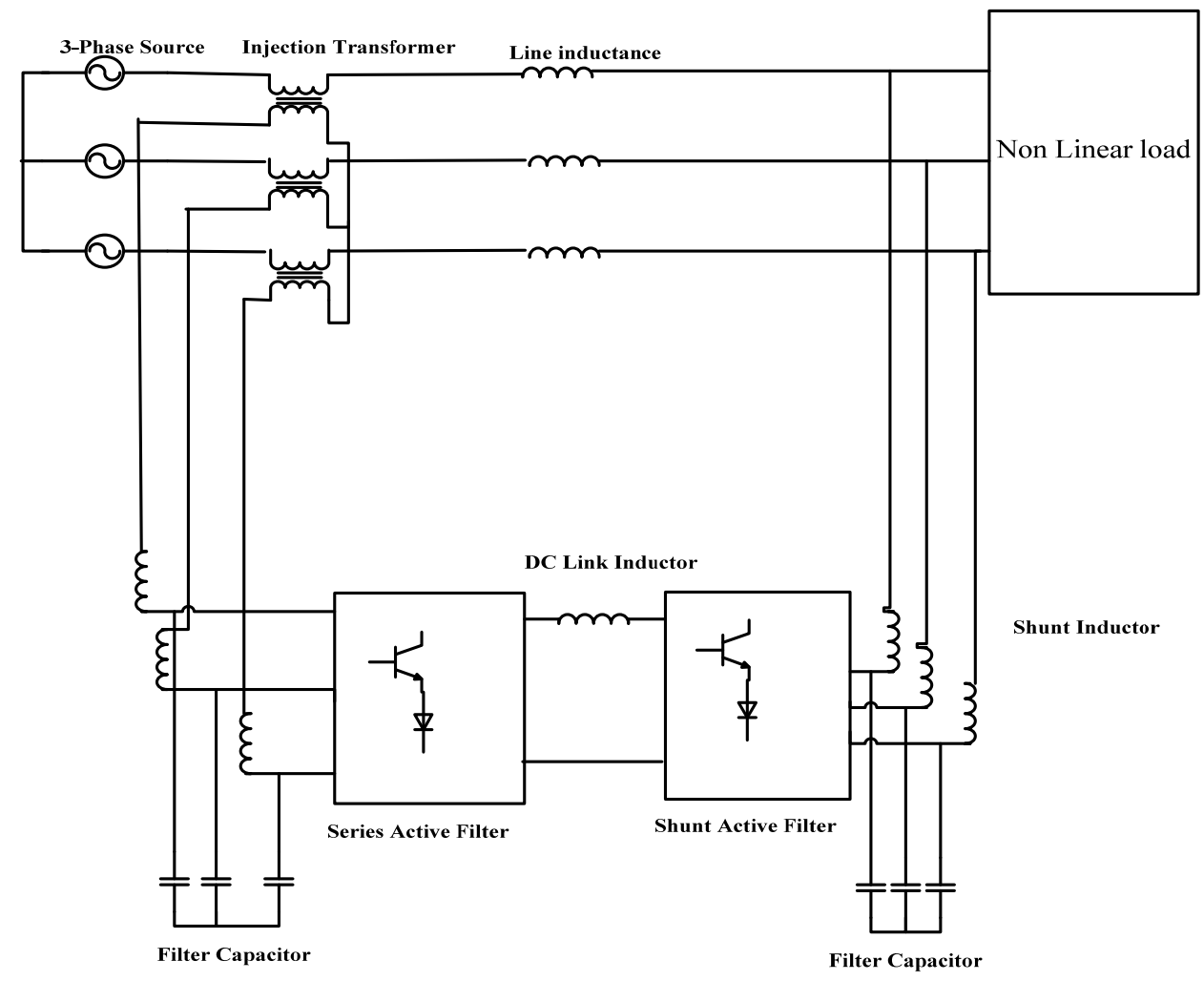


Figure 3 Control block diagram of series filter controller

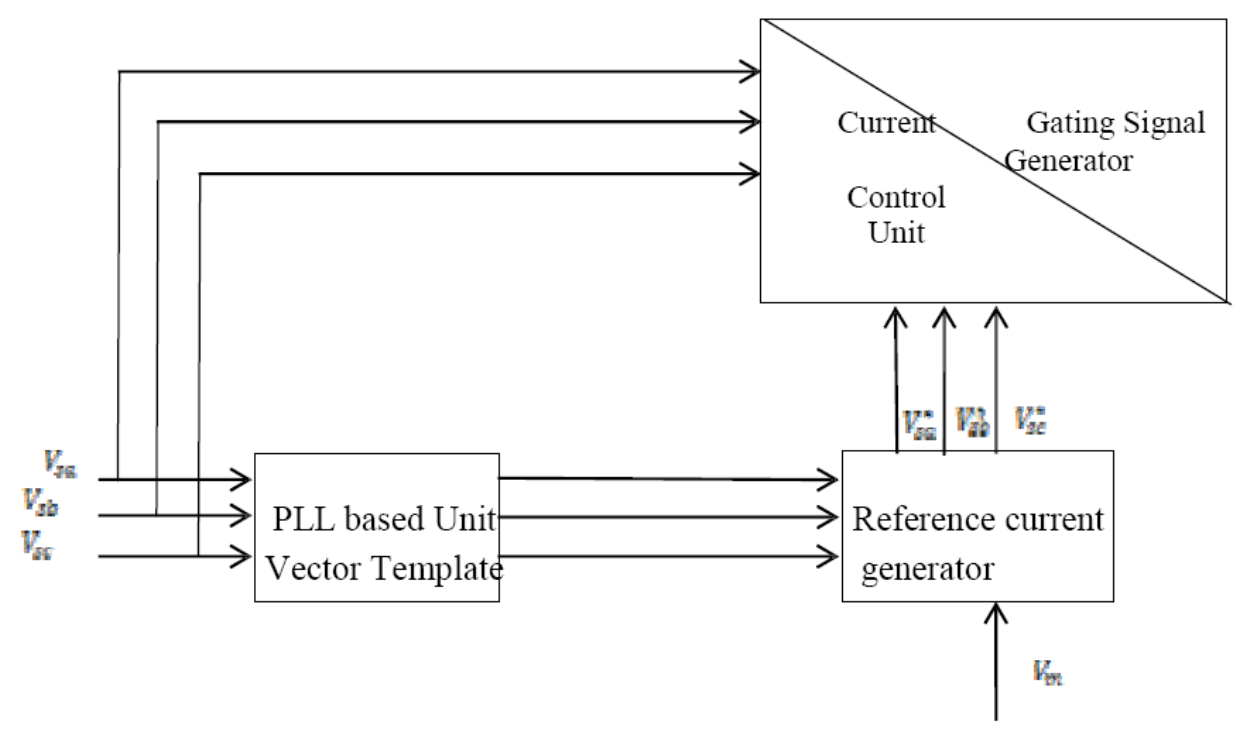

Figure 4 Control block diagram of shunt filter controller

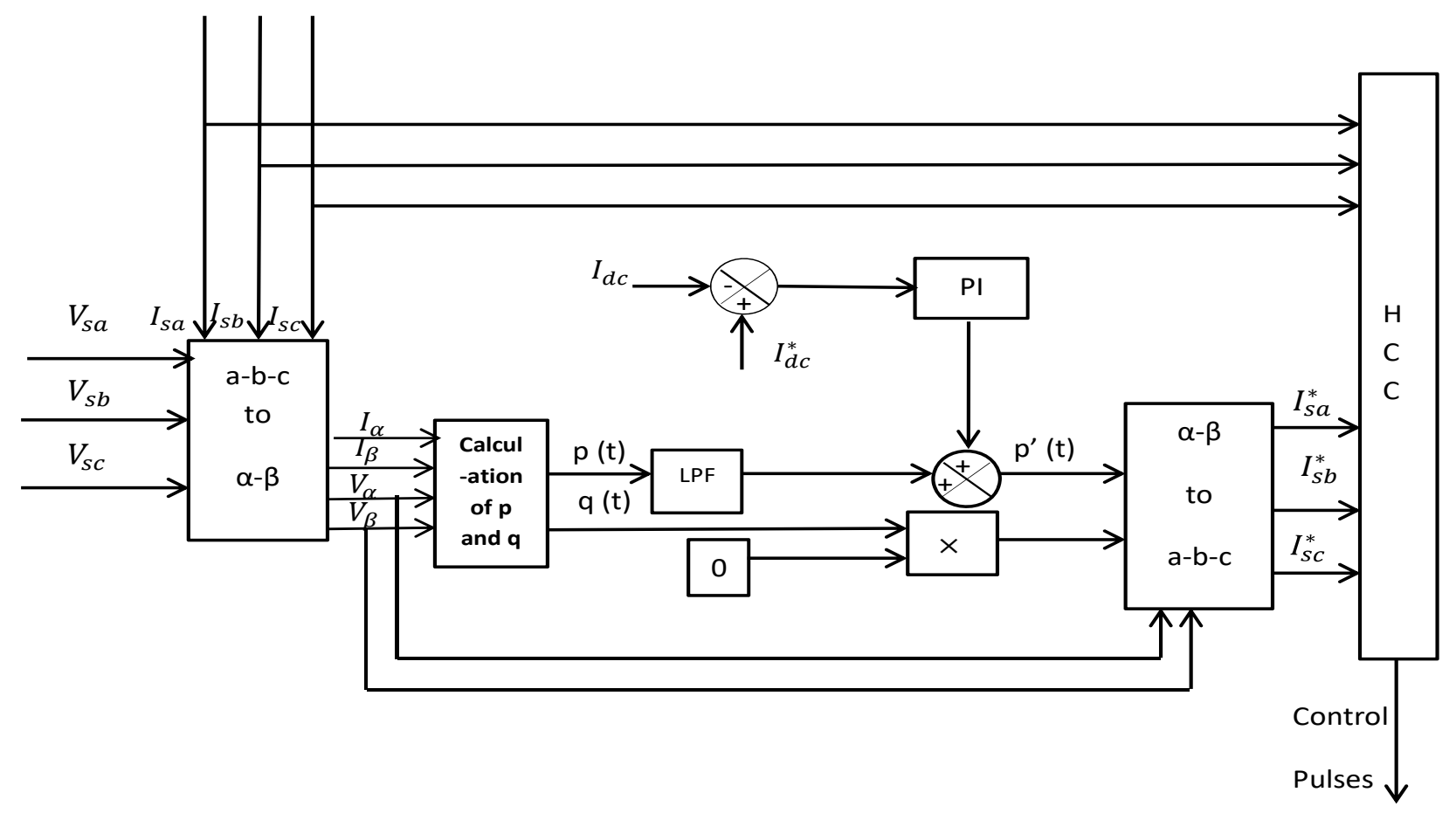

\subsection{Shunt filter controller}

In CSI-based UPQC, the DC link current is sensed and compared with reference DC link current to generate an error signal. The error signal is then processed through the PI controller. The output signal from PI controller is treated as switching power losses of shunt active filter, and is added to real power loss component to derive reference source current using equations (14) to (23). The switching signals of shunt inverter are derived by comparing these reference currents with actual source current in a hysteresis controller band. The schematic block diagram of shunt filter controller is shown in Figure 4.
In the block diagram of Figure 4, distorted source voltage and source current are multiplied to yield instantaneous active and reactive power. Then the dc component of active power is separated with the help of low pass filter and reactive power is set to zero. Also the dc link current is compared with the reference current and passed through a PI controller and added with the dc component of instantaneous real power. After this inverse Clarke transformation is performed to give reference source current, and are subsequently used to generate control pulses.

In shunt filter controller, instantaneous three-phase currents and voltages are transformed into a three 
coordinates from a-b-c coordinates, known as Clarke transformation as given in equation (13).

$$
\left[\begin{array}{l}
v_{\alpha} \\
v_{\beta}
\end{array}\right]=\sqrt{\frac{2}{3}}\left[\begin{array}{rrr}
1 & -\frac{1}{2} & -\frac{1}{2} \\
0 & \frac{\sqrt{3}}{2} & -\frac{\sqrt{3}}{2}
\end{array}\right]\left[\begin{array}{l}
v_{a} \\
v_{b} \\
v_{c}
\end{array}\right]
$$

Basically Clarke transformation is used for converting a time variant frame of reference to an invariant frame of reference. Instantaneous active and reactive powers in orthogonal co-ordinates are calculated as follows,

$$
\begin{aligned}
& p(t)=v_{\alpha}(t) i_{\alpha}(t)+v_{\beta}(t) i_{\beta}(t) \\
& q(t)=-v_{\beta}(t) i_{\alpha}(t)+v_{\alpha}(t) i_{\beta}(t)
\end{aligned}
$$

From above equations, the instantaneous power can be rewritten as shown below in equation (16) as,

$$
\left[\begin{array}{l}
p \\
q
\end{array}\right]=\left[\begin{array}{cc}
v_{\alpha} & v_{\beta} \\
-v_{\beta} & v_{\alpha}
\end{array}\right]\left[\begin{array}{l}
i_{\alpha} \\
i_{\beta}
\end{array}\right]
$$

where $\mathrm{p}-$ instantaneous real power, $\mathrm{q}-$ instantaneous reactive power.

From (14) and (15), the values of $p$ and $q$ can be expressed in terms of DC components plus the AC components as follows,

$$
\begin{aligned}
& p=\bar{p}+\tilde{p} \\
& q=\bar{q}+\tilde{q}
\end{aligned}
$$

where $\bar{p}$ is the dc component of the instantaneous power $\mathrm{p}$, and is related to the fundamental active current.

$\tilde{p}$ is the ac component of the imaginary power $\mathrm{p}$ and is related to the harmonic current caused by the ac component of the instantaneous real power

$\bar{q}$ is the AC component of the imaginary instantaneous power $\mathrm{q}$ and is related to the reactive power generated by the fundamental components of voltage and current.

$\tilde{q}$ is the AC component of the instantaneous imaginary power $\mathrm{q}$ and is related to the harmonic current caused the ac component of instantaneous reactive power.

For computation of harmonic free unity power factor 3-phase currents, compensating powers $p_{c}$ and $q_{c}$ are selected as,

$$
\begin{aligned}
& p_{c}=\bar{p}+p_{\text {loss }} \\
& q_{c}=0
\end{aligned}
$$

where $p_{\text {loss }}$ is the instantaneous active power corresponding to the switching loss and resistive loss of shunt active filter. The orthogonal components of the fundamental current are obtained as follows,

$$
\left[\begin{array}{l}
i_{\alpha} \\
i_{\beta}
\end{array}\right]=\left[\begin{array}{cc}
v_{\alpha} & v_{\beta} \\
-v_{\beta} & v_{\alpha}
\end{array}\right]^{-1}\left[\begin{array}{l}
p_{c} \\
q_{c}
\end{array}\right]
$$

The a-b-c components of fundamental reference current are obtained as follows:

$$
\left[\begin{array}{c}
i_{s a}^{*} \\
i_{s b}^{*} \\
i_{s c}^{*}
\end{array}\right]=\left[\begin{array}{cc}
2 / 3 & 0 \\
-1 / 3 & 1 / \sqrt{ } 3 \\
-1 / 3 & -1 / \sqrt{ } 3
\end{array}\right]\left[\begin{array}{c}
i_{\alpha} \\
i_{\beta}
\end{array}\right]
$$

The control of CSI-based UPQC is realised using hysteresis band PWM technique. Among different PWM techniques, the hysteresis band control is used very often. The hysteresis band is used because of its simplicity of implementation, fast response and does not need any knowledge of load parameters. In hysteresis control switching signals are derived by comparing the signal error with a fixed tolerance band.

\section{Performance evaluation}

To justify the performance capability, CSI-based UPQC model is developed using above equations in MATLAB/SIMULINK and SimPowerSystems software. Nonlinear load is employed using three-phase diode rectifier with an RL load. All the compensators are implemented using equivalent discrete blocks. Shunt filter is switched on at $0.05 \mathrm{sec}$. while series filter is switched on at $0.1 \mathrm{sec}$ to verify the performance of industrial filters. The system parameters are selected as mentioned in Table 1.

Table $1 \quad$ System parameters

\begin{tabular}{lc}
\hline System parameters & Values \\
\hline Source voltage & $230(\mathrm{RMS})$ \\
System frequency & 50 \\
Load impedance & $150 \Omega, 40 \mathrm{mH}$ \\
DC link inductance & $160 \mathrm{mH}$ \\
Reference current & $6 \mathrm{Amps}$ \\
Source impedance & $0.01 \Omega, 50 \mu \mathrm{H}$ \\
\hline
\end{tabular}

In order to simulate source voltage distortion, a $10 \%$ of 5 th harmonic and $5 \%$ of 7 th harmonic are added to the fundamental. A hysteresis band of \pm 0.05 is considered for simulation study. Filter parameters are shown in Table 2.

Table 2 Filter parameters

\begin{tabular}{lc}
\hline \multicolumn{2}{c}{$C S I$} \\
\hline DC link inductance & $160 \mathrm{mH}$ \\
Series filter reactance & $1 \Omega, 25 \mu \mathrm{F}$ \\
Shunt filter reactance & $1.5 \Omega, 25 \mu \mathrm{F}$ \\
\hline
\end{tabular}

A PLL-based unit vector template is used for obtaining reference values. Unit vector templates for different phase input voltage is unitised by multiplying with gain factor equal to its peak amplitude and then passed through phased locked loop to obtain proper phase delay. The unit vector templates thus obtained are shown below in Figure 5. 
Figure 5 Unit vector template

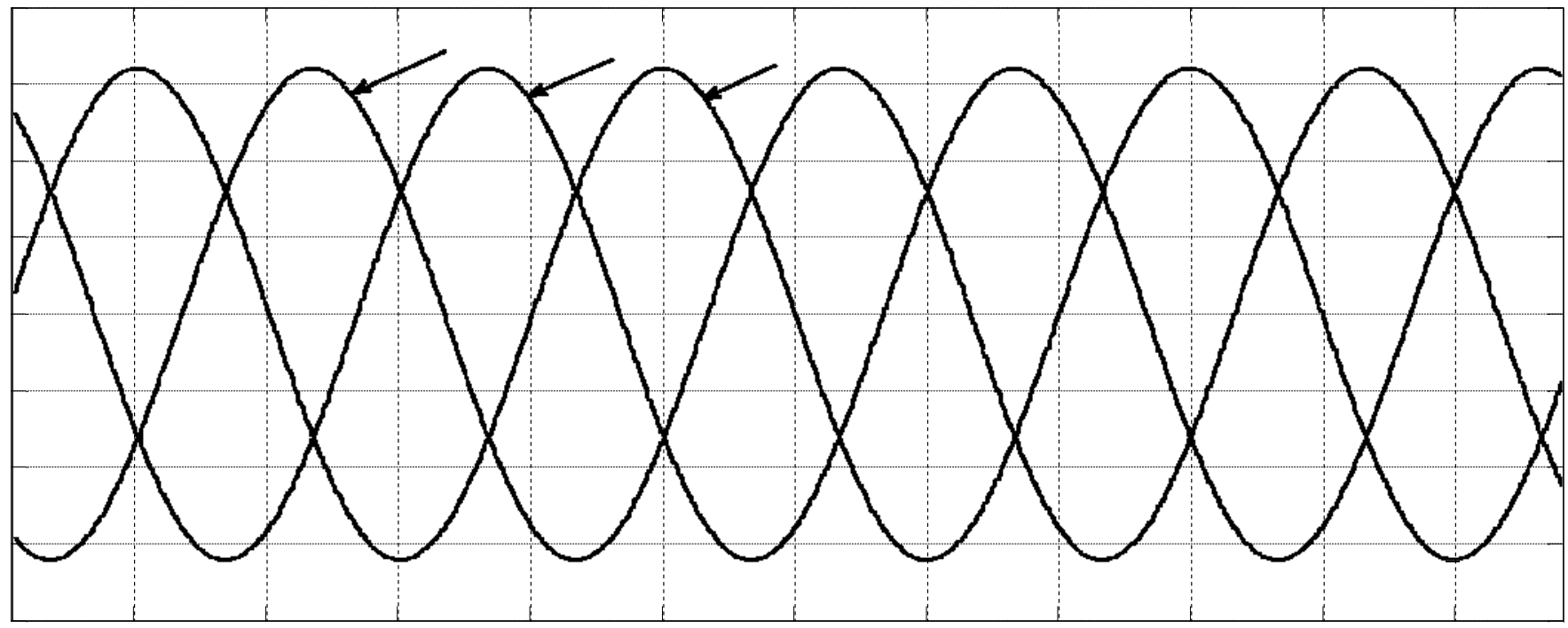

Figure 6 (a) Source voltage (b) Load voltage (c) Required compensation (d) Compensation signal
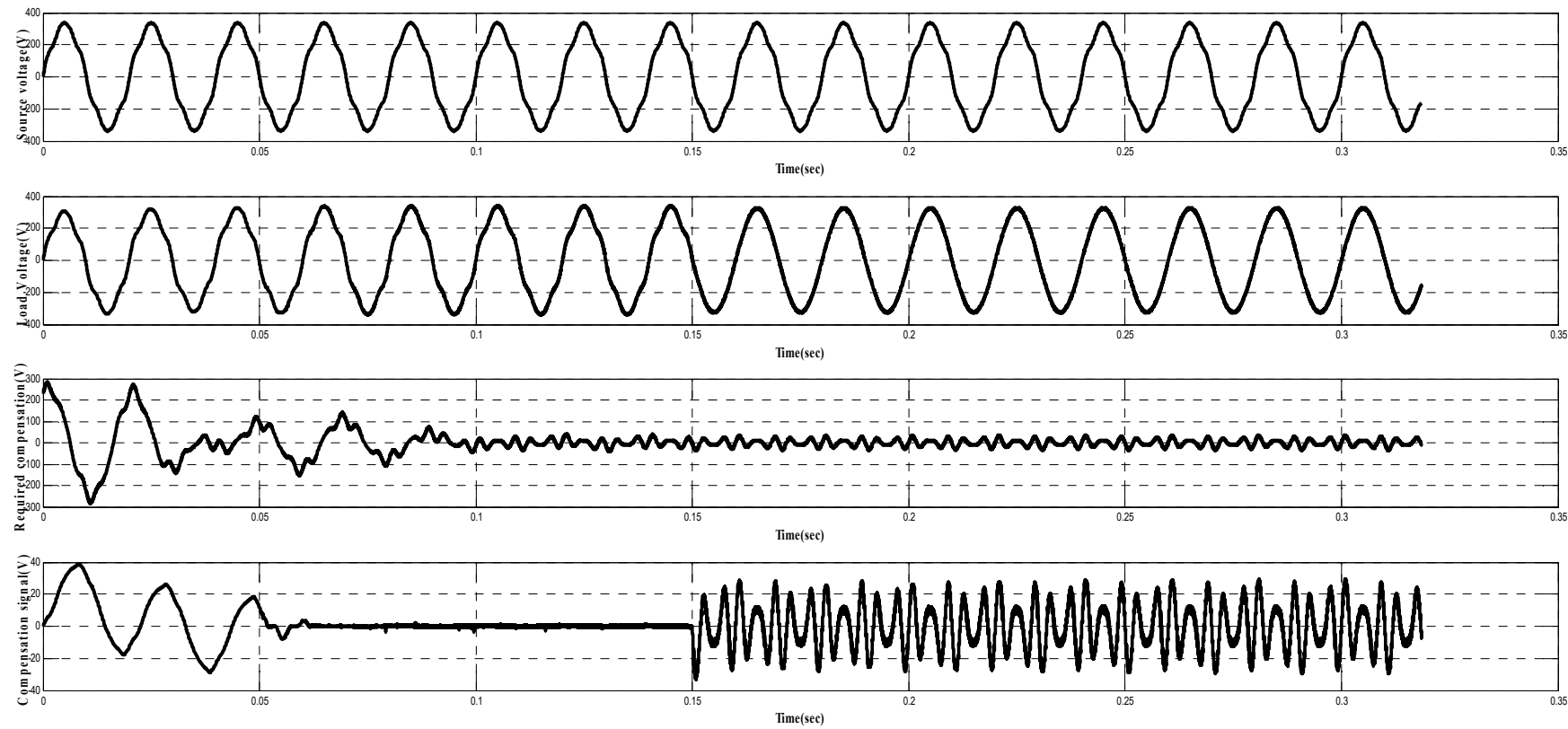

From the unit vector thus obtained, reference load voltages can be obtained by multiplying with unit magnitude equal to peak of load voltage. The performance of UPQC for voltage harmonic correction depends on series filter performance. The load voltage is same as source voltage, till the series filter is switched on; As the series filter is switched on at $0.1 \mathrm{sec}$. the load voltage becomes purely sinusoidal as indicated in Figure 6. The THD of load voltage is same as that of source voltage that is $6.87 \%$ before series filter is activated. This is shown in harmonic spectrum of source voltage shown in Figure 7(a). The load voltage THD is reduced to just $0.72 \%$ by series filter as shown in harmonic spectrum of load voltage in Figure 7(b).
Hence compensating for voltage harmonics present in the system and thus, the system voltage to become sinusoidal at PCC irrespective of voltage distortions present at the source.

It can be seen from Figure 8 that once the shunt active filter starts its operation at $\mathrm{t}=0.05 \mathrm{sec}$, the source current becomes sinusoidal and the shunt filter starts compensation. Also it can be observed that load current is non-sinusoidal and has a THD of $28.85 \%$ as shown in harmonic spectrum of load current in Figure 9(a). As soon as shunt active filter is activated, the source current becomes sinusoidal with a THD of $2.30 \%$ as shown in harmonic spectrum of source current in Figure 9(b). 
Figure 7 (a) Harmonic spectrum of source voltage (b) Harmonic spectrum of load voltage (see online version for colours)

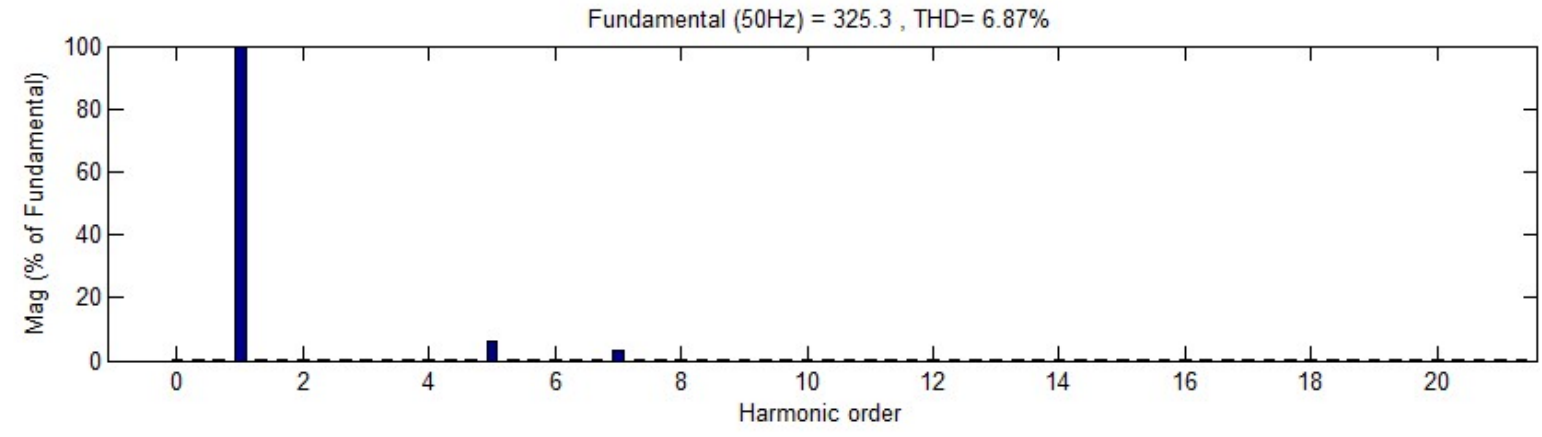

(a)

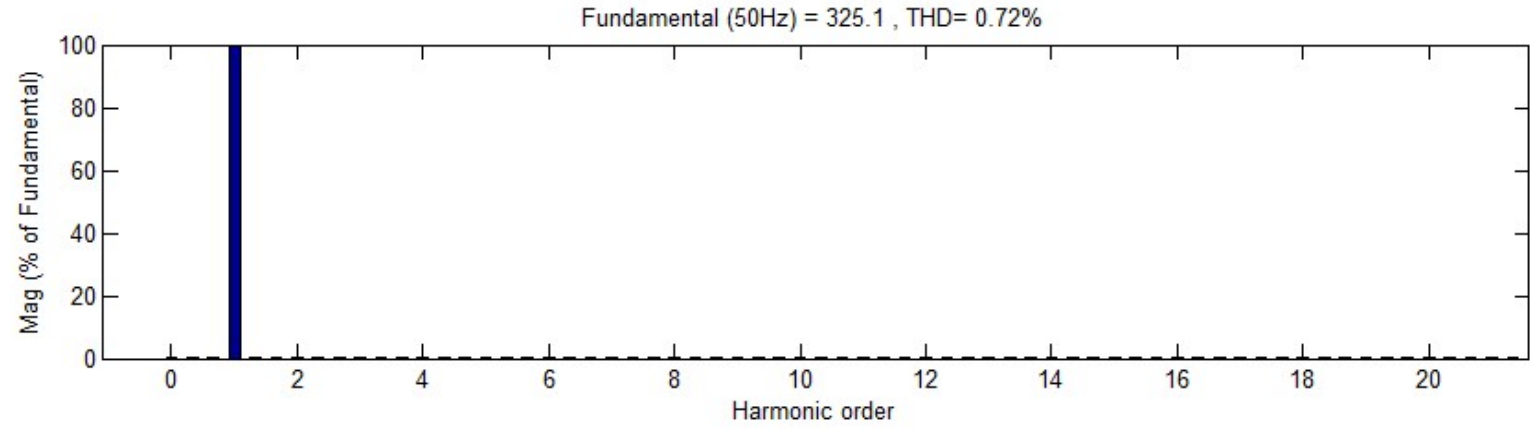

(b)

Figure 8 Source current, load current and filter current
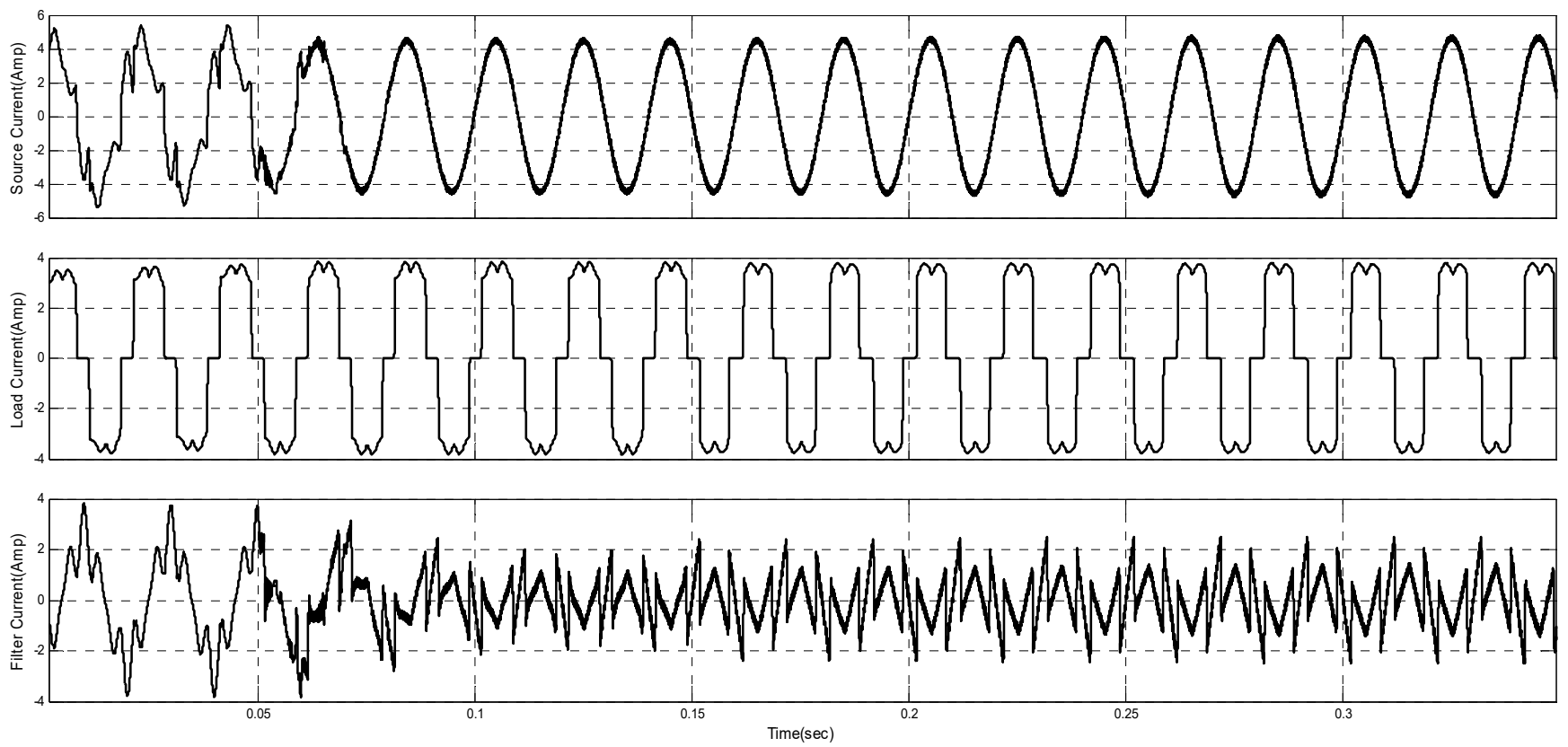
Figure 9 (a) Harmonic spectrum of source current (b) Harmonic spectrum of load current (see online version for colours)

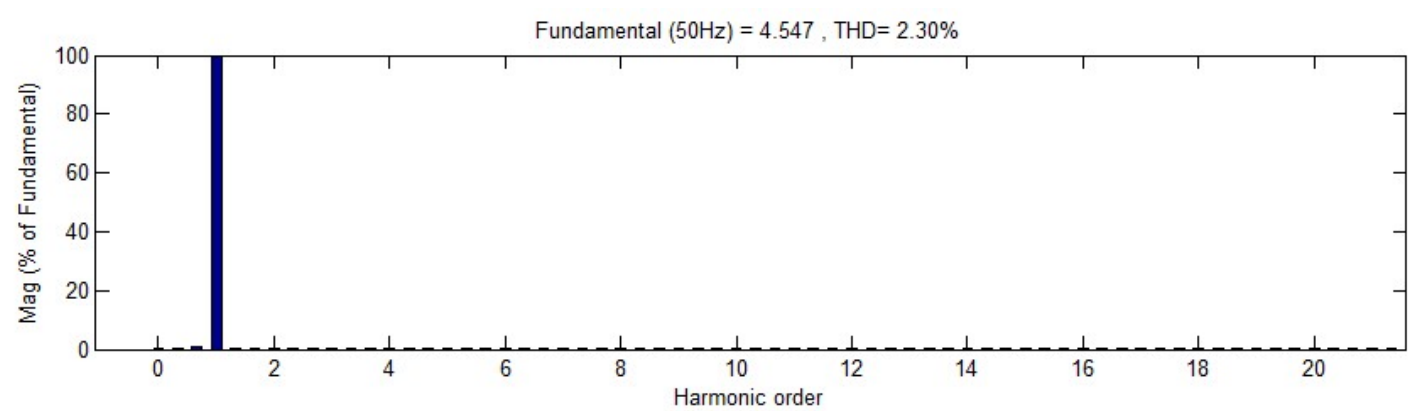

(a)

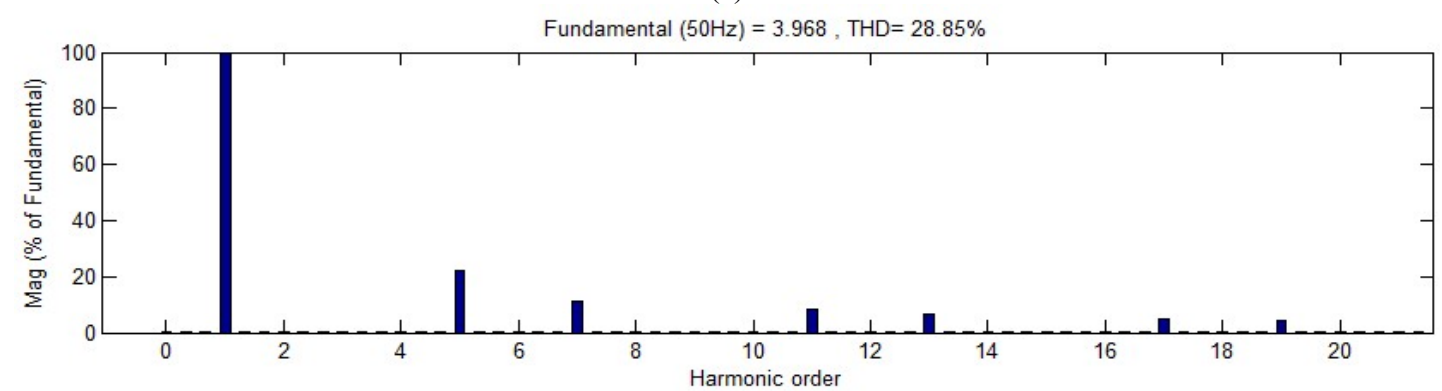

(b)

Figure 10 Plot of source current (Vs), source current (Is) vs time (sec)

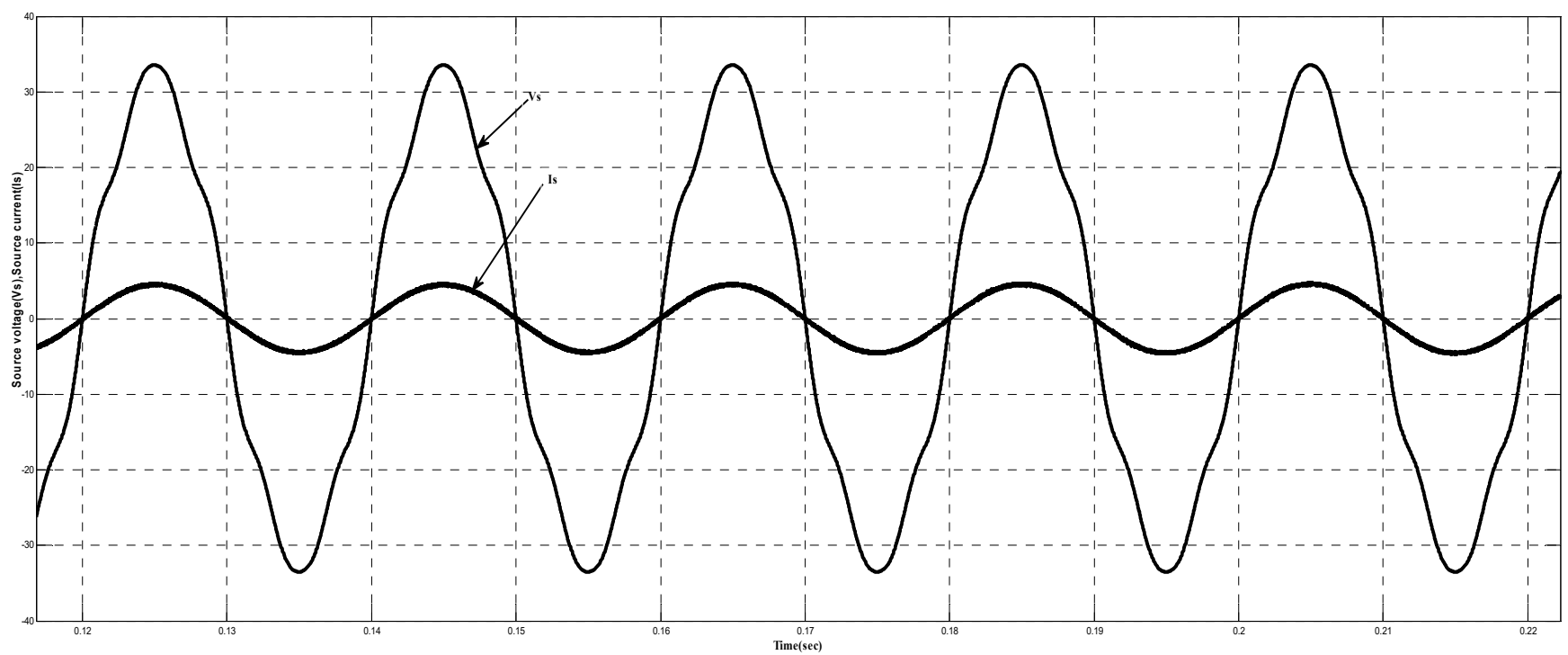

Also it can be seen from comparison of source voltage and source current that both are in phase and unity power factor is maintained as shown in Figure 10.

For step variation in load, first load resistance is changed from $150 \mathrm{ohms}$ to100 ohms. The UPQC behaves perfectly as can be seen from Figure 11. In Figure 12, the current is shown, at $\mathrm{t}=0.3 \mathrm{sec}$ the load is changed and some transients are there but after some time source current becomes sinusoidal. Also in Figure 13 source voltage and source current are shown which are in phase and unity power factor is maintained. In Figure 14(a) and Figure 14(b), harmonic spectrum of respective load voltage and source current is shown which is well below 5\% (THD of load voltage is $1.0 \%$ and that of source current is $1.98 \%$ ).
After this load resistance and load inductance both are changed at $\mathrm{t}=.3 \mathrm{sec}$ (resistance is changed to $100 \Omega$ from $150 \Omega$ and load inductance is changed to $10 \mathrm{mh}$ from $50 \mathrm{mh}$ ). Again the UPQC works perfectly for voltage harmonics as shown in Figure 15. In Figure 16, various currents are shown (source current, load current, filter current) and the source current is becoming perfectly sinusoidal. In Figure 17 , source current and source voltage are plotted which are in phase maintaining unity power factor, thus the UPQC is working for this change in RL load also. In Figure 18(a) and Figure 18(b), harmonic spectrum of load voltage and source current is shown which is well within the required limits (THD of load voltage is $1.06 \%$ and that of source current is $1.99 \%)$. 
Figure 11 Source voltage, load voltage, required compensation, compensation signal for step change in $\mathrm{R}$ load at $\mathrm{t}=.3 \mathrm{sec}$.

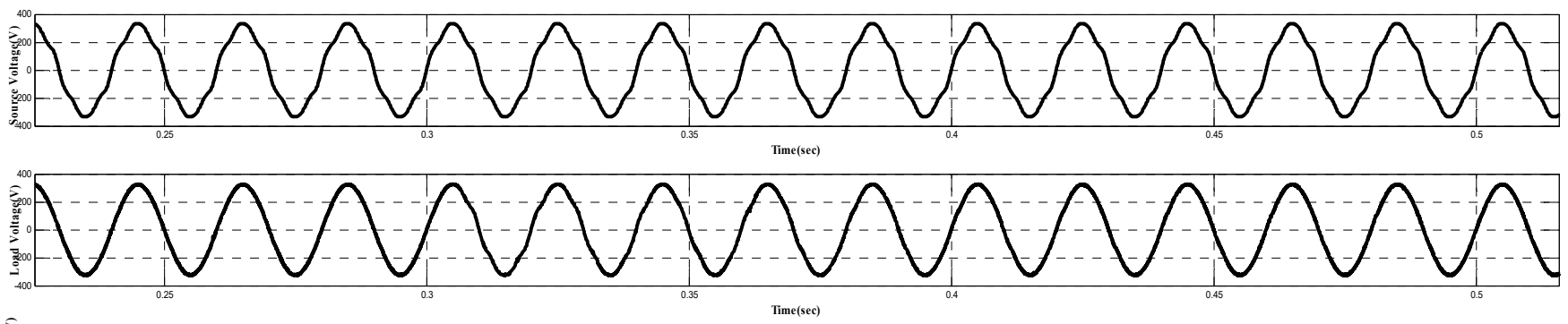

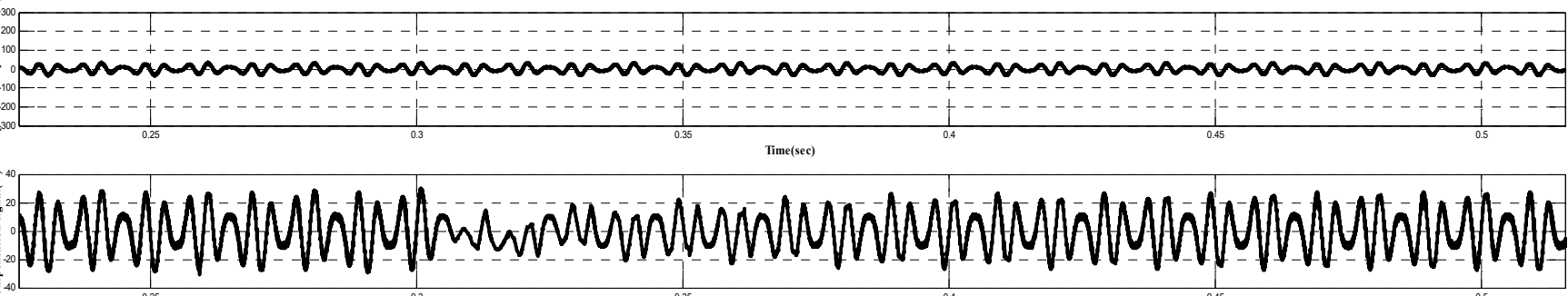

Figure 12 Source current, load current and filter current for step change in $\mathrm{R}$ load at $\mathrm{t}=.3 \mathrm{sec}$.

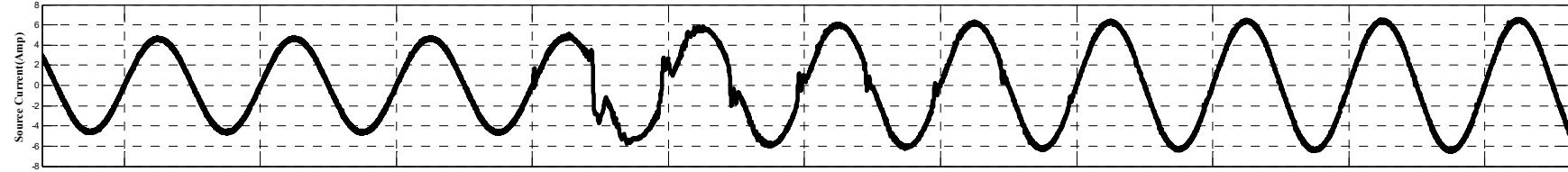

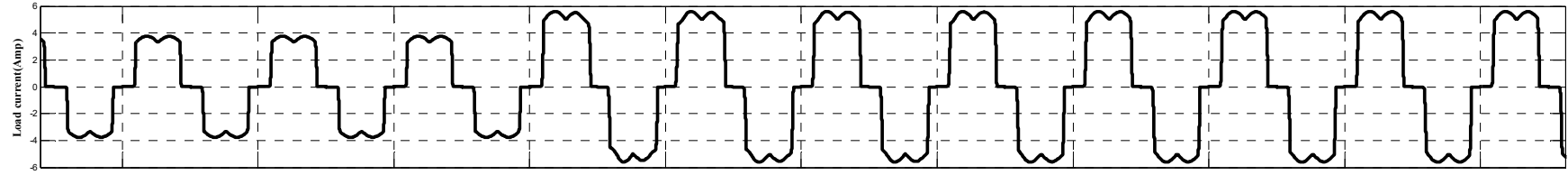

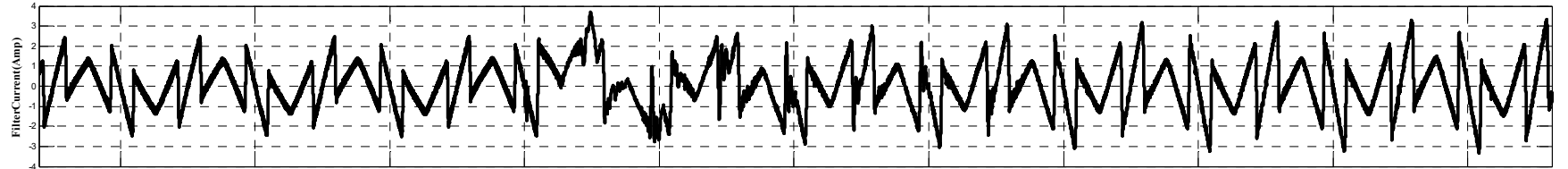

Figure 13 Source voltage and source current for step change in R-load at $t=.3 \mathrm{sec}$.

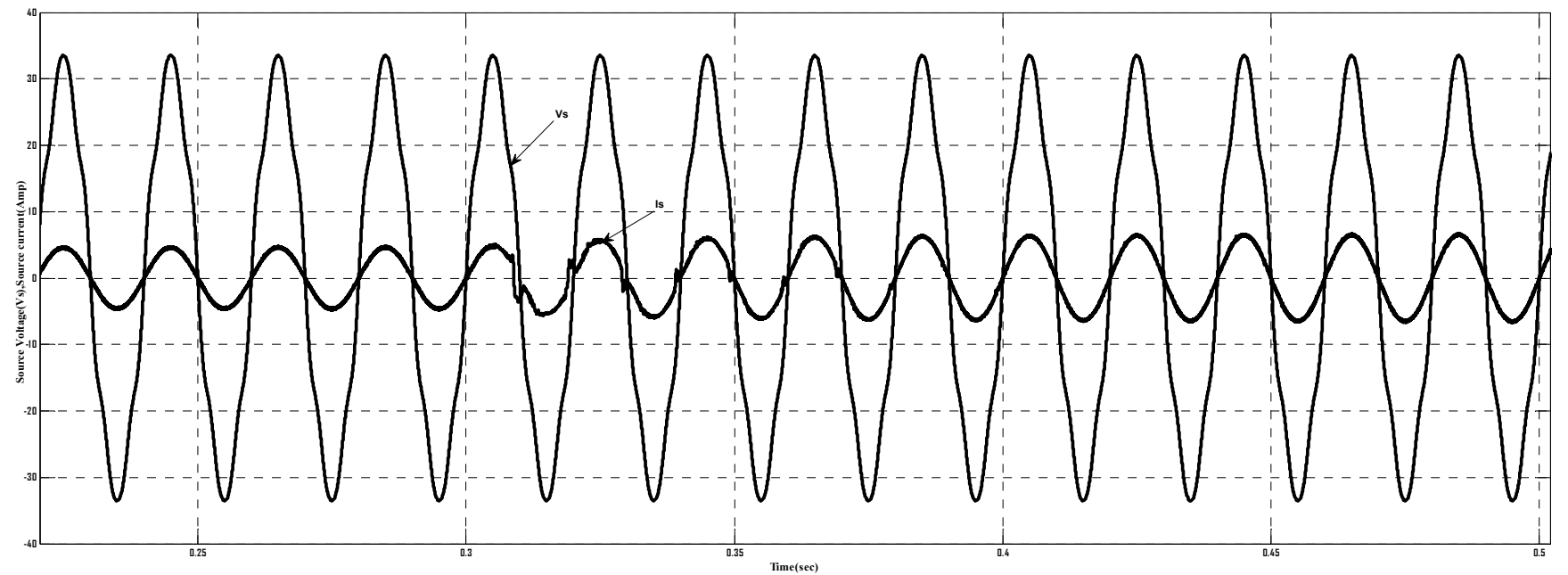


Figure 14 (a)Harmonic spectrum of load voltage after step chenge in R-load at $t=.3 \mathrm{sec}$. (b) Harmonic spectrum of source current after step change in R-load at $\mathrm{t}=.3 \mathrm{sec}$. (see online version for colours)

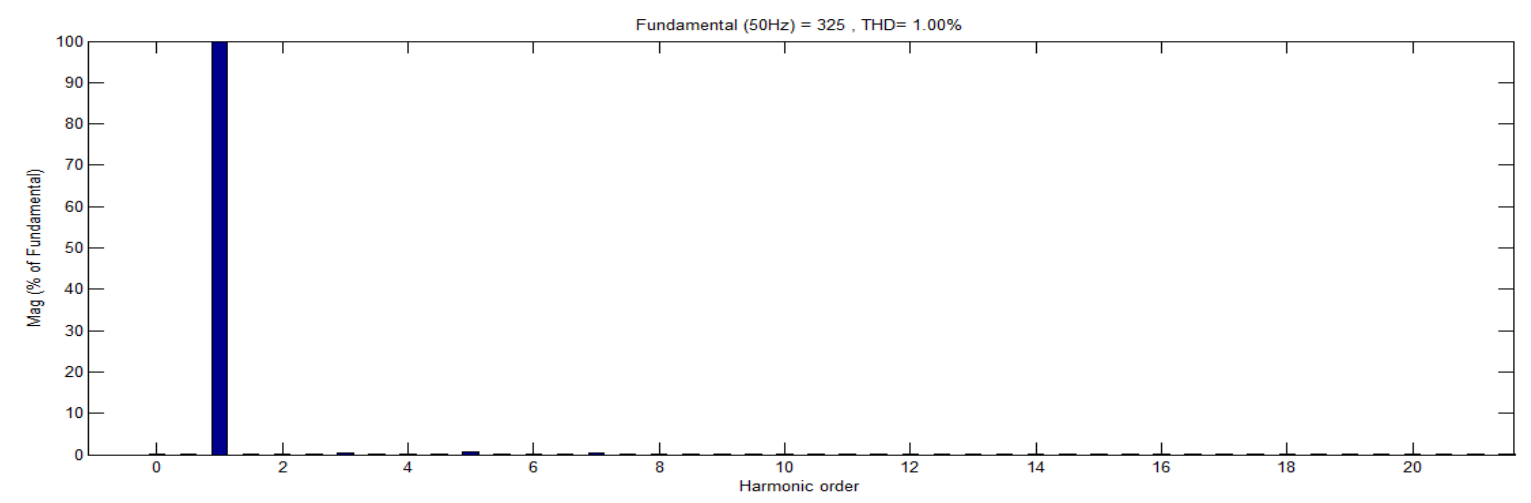

(a)

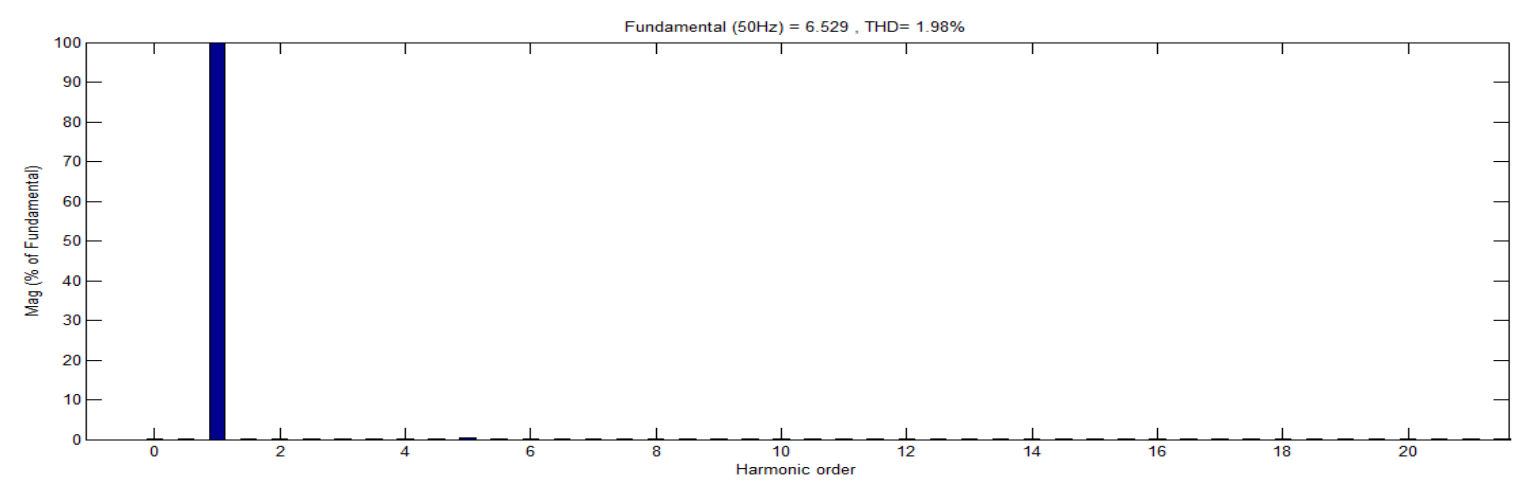

(b)

Figure 15 Source voltage, load voltage, required compensation, compensation signal for step change in R-L load at $t=.3$ sec.
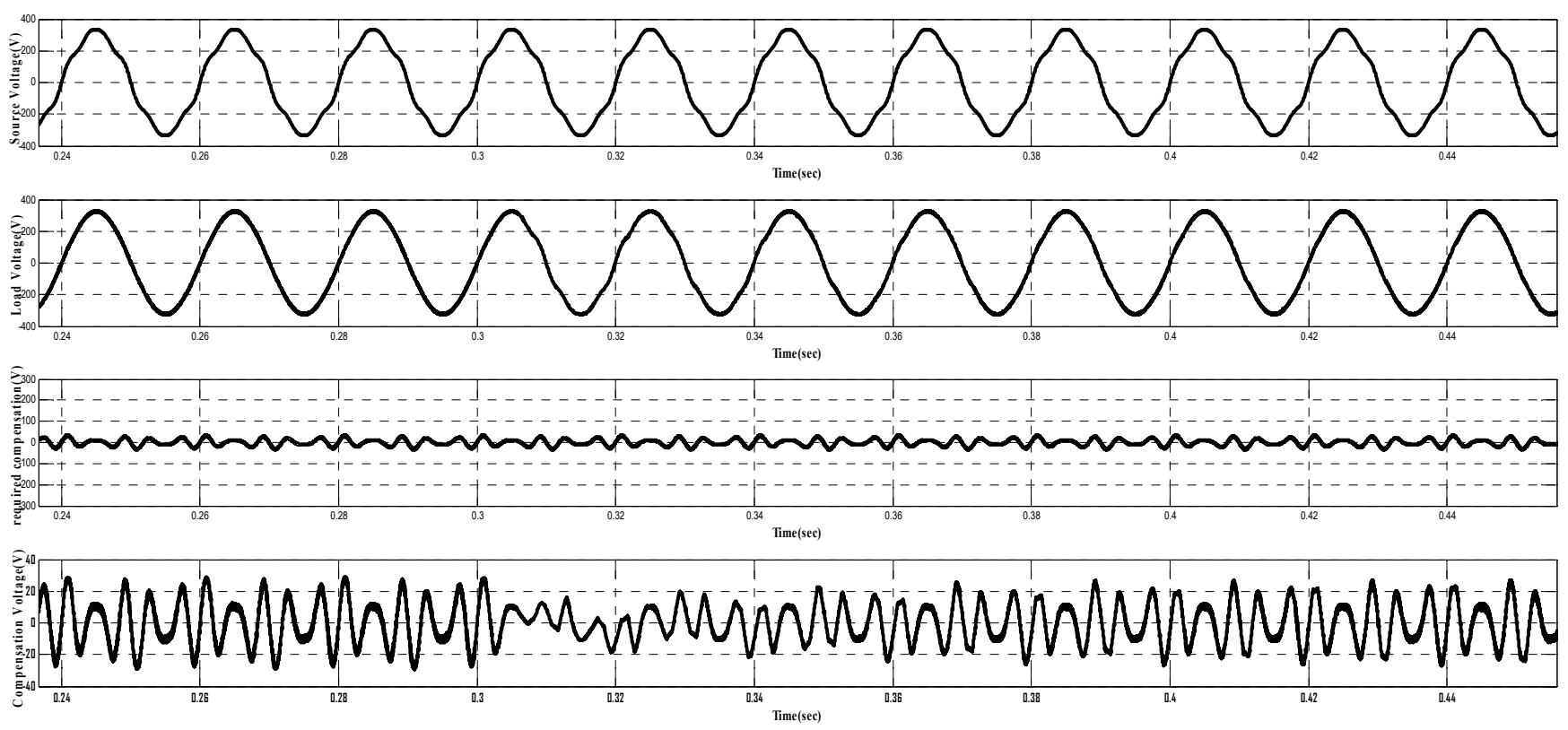
Figure 16 Source current, load current and filter current for step change in R-L load at $t=.3 \mathrm{sec}$.
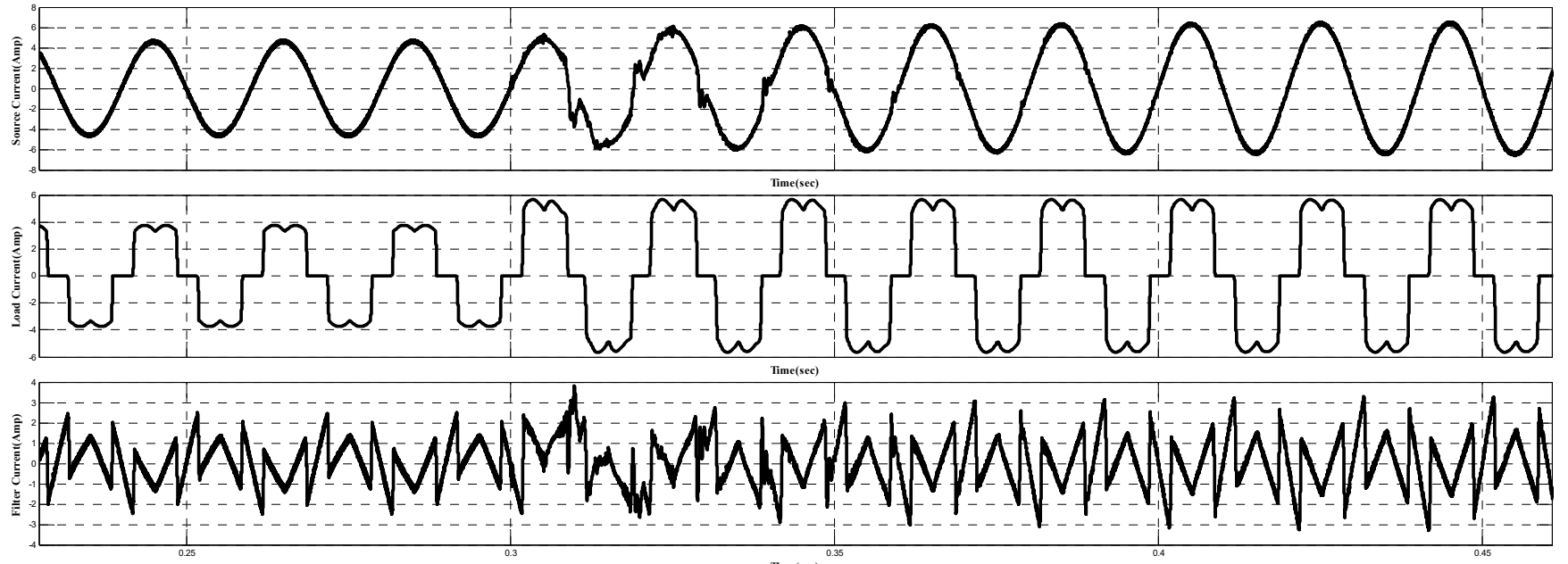

Figure 17 Source voltage and source current for step change in R-L load at $\mathrm{t}=.3 \mathrm{sec}$.

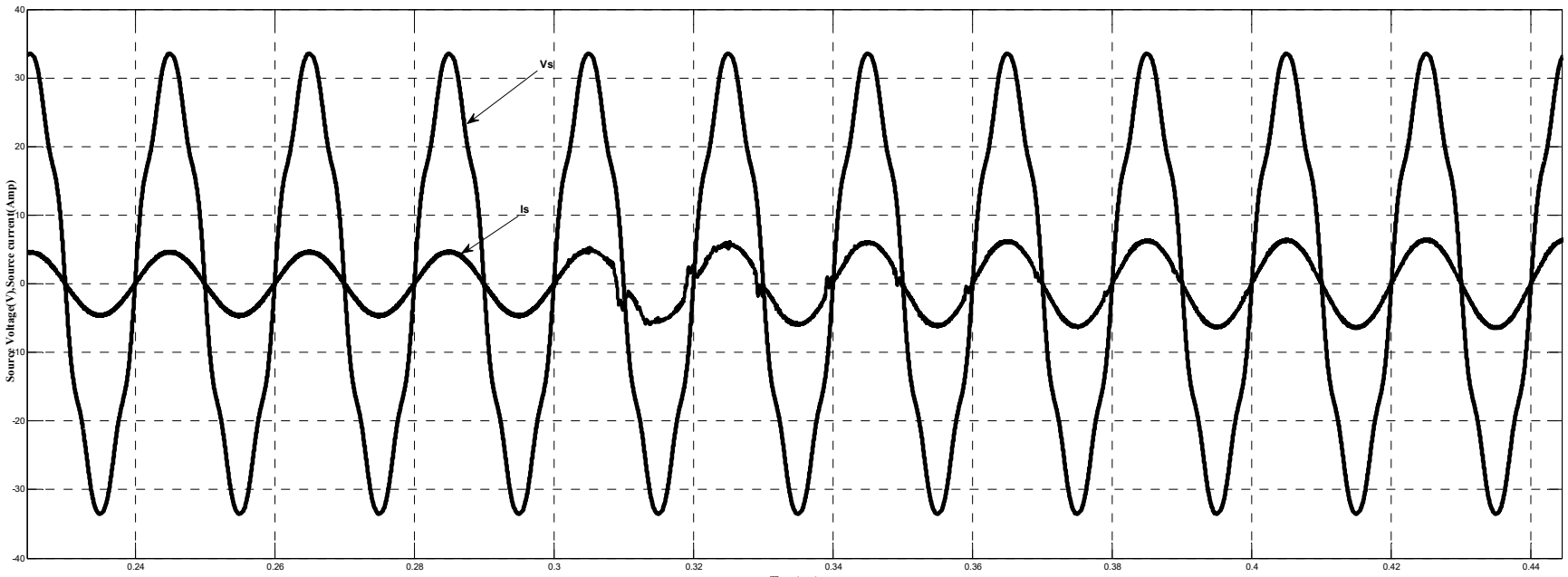

Figure 18 (a) Harmonic spectrum of load voltage after step chenge in R-L-load at $t=.3 \mathrm{sec}$. (b) Harmonic spectrum of source current after step change in R-L-load at $\mathrm{t}=.3 \mathrm{sec}$. (see online version for colours)

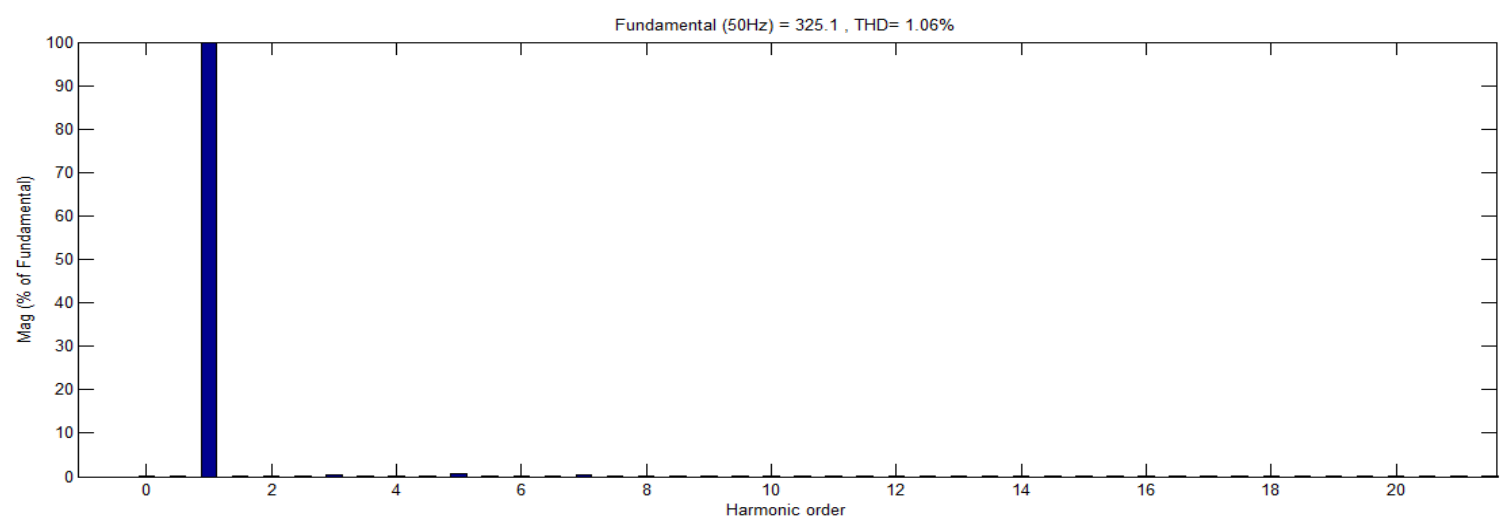

(a) 
Figure 18 (a) Harmonic spectrum of load voltage after step chenge in R-L-load at $t=.3 \mathrm{sec}$. (b) Harmonic spectrum of source current after step change in R-L-load at $\mathrm{t}=.3 \mathrm{sec}$. (continued) (see online version for colours)

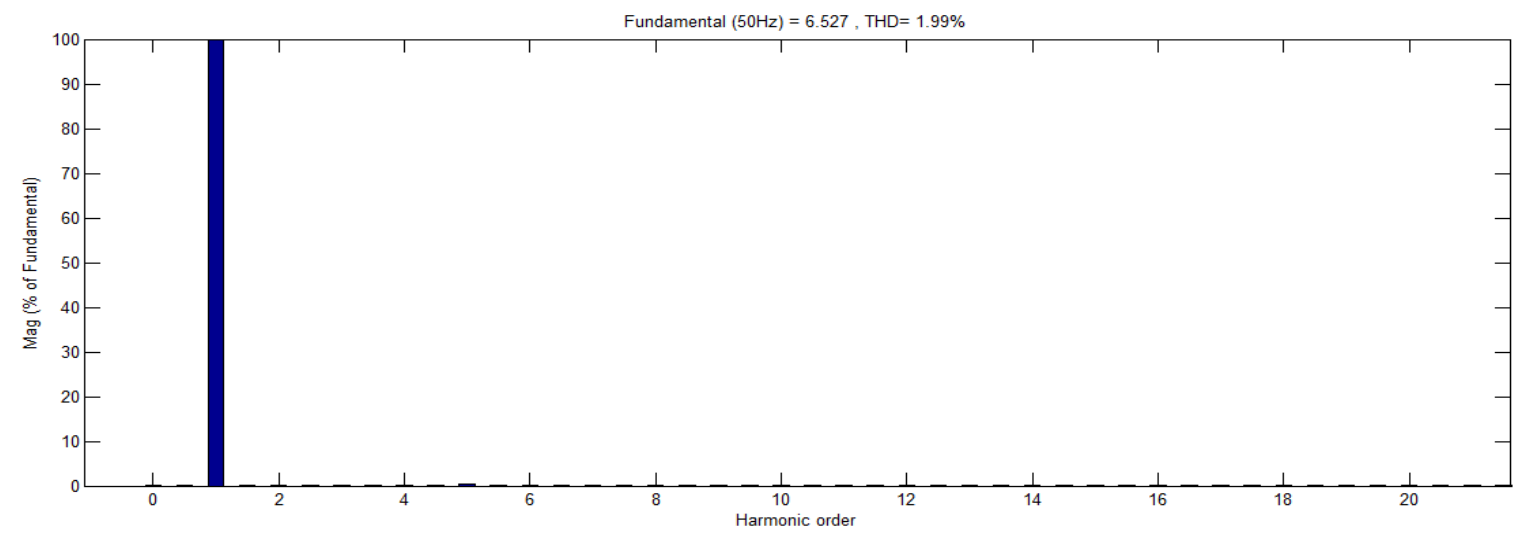

(b)

Figure 19 Source voltage, load voltage, required compensation, compensation signal for load having filter capacitor
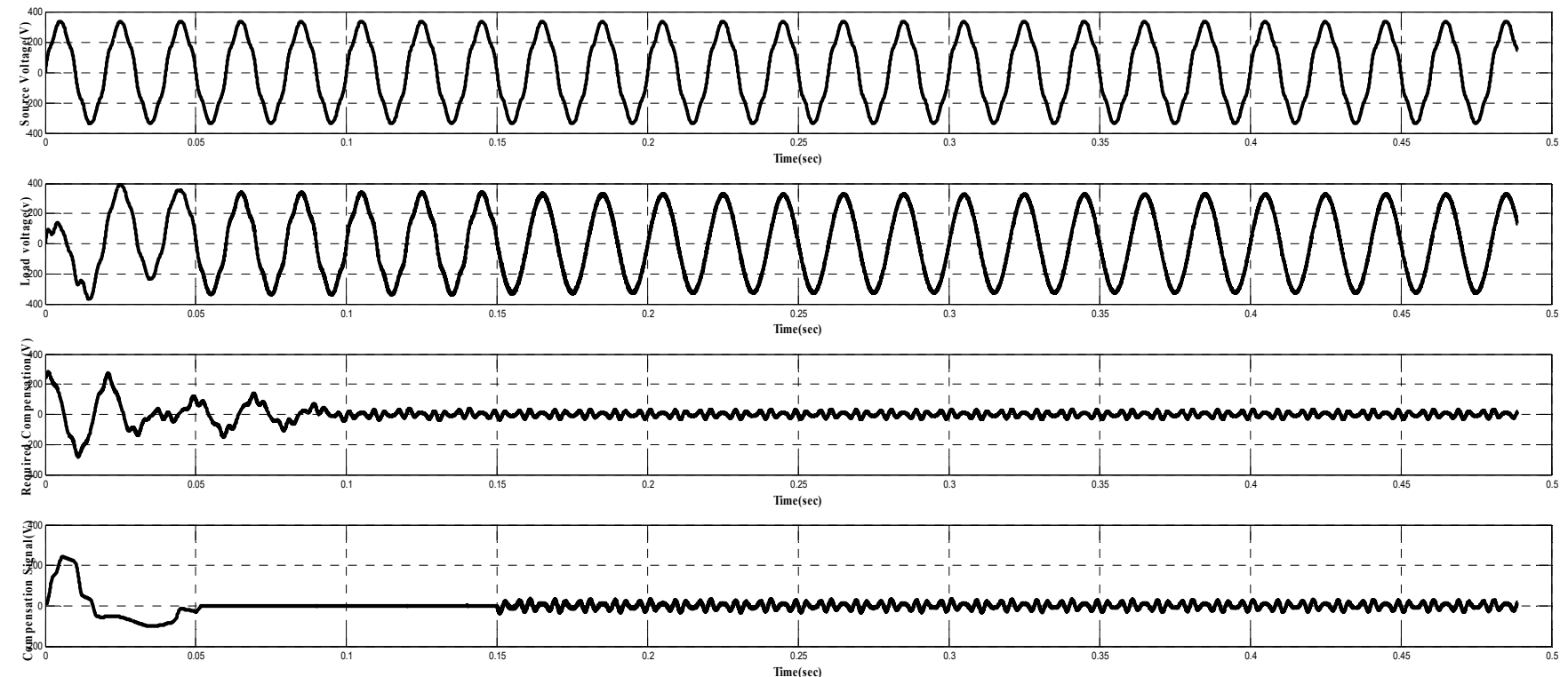

Figure 20 Source current, load current and filter current for load having filter capacitor
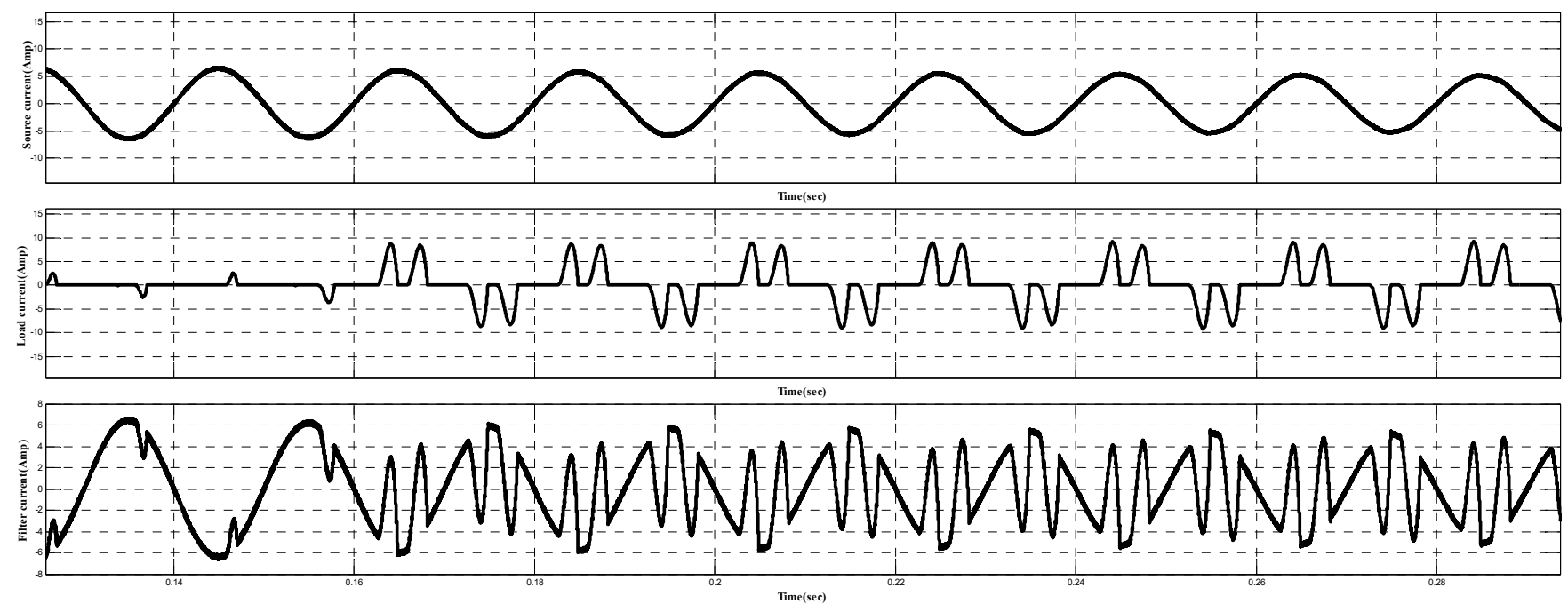
At last filter capacitor is attached across R-L load $(\mathrm{C}=1,000 \mu \mathrm{F})$. Again voltage harmonics are eliminated perfectly as shown in Figure 19, subsequently current harmonics are also eliminated as shown in Figure 20. In Figure 21, source voltage and source current are shown which are in phase and unity power factor is maintained.
Also for this case the harmonic spectrum is shown in Figure 22(a) and Figure 22(b) for load voltage and source current respectively. These are also within required limits (THD of load voltage is $0.81 \%$ and that of source current is $2.98 \%)$.

Figure 21 Source voltage and source current for load having filter capacitor

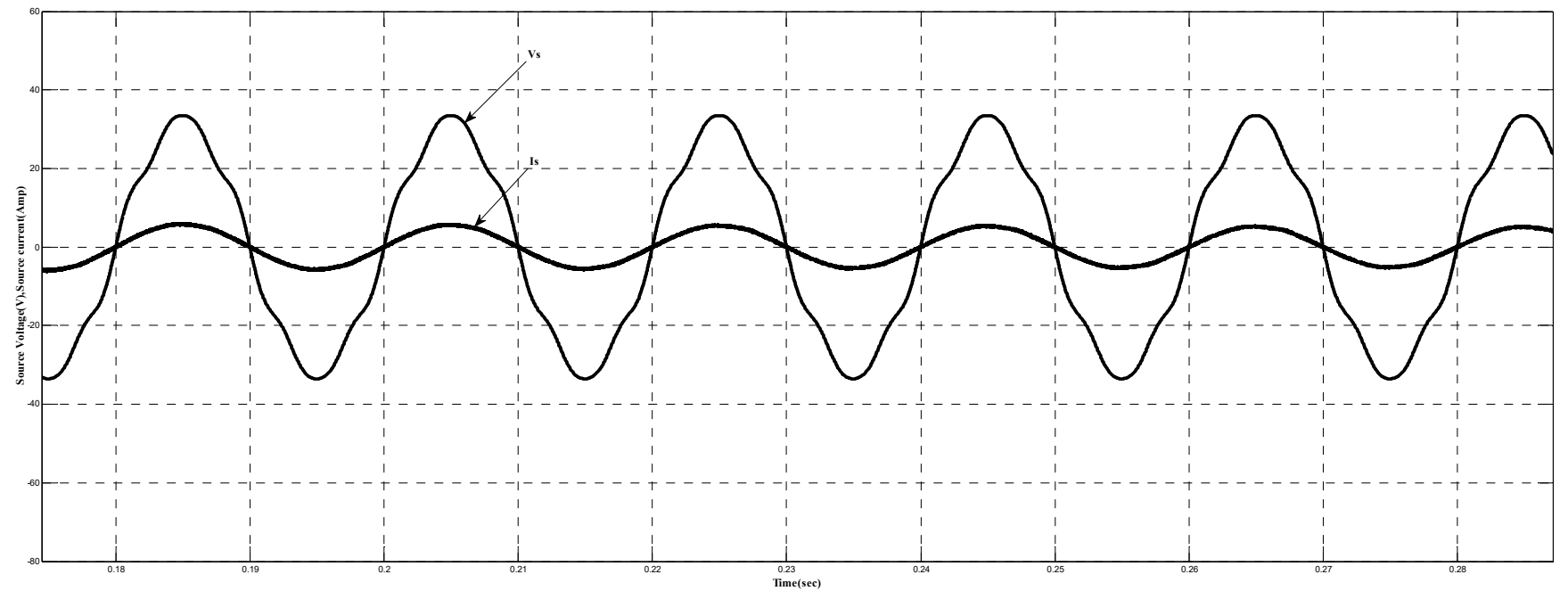

Figure 22 (a) Harmonic spectrum of load voltage for load having filter capacitor (b) Harmonic spectrum of source current for load having filter capacitor (see online version for colours)

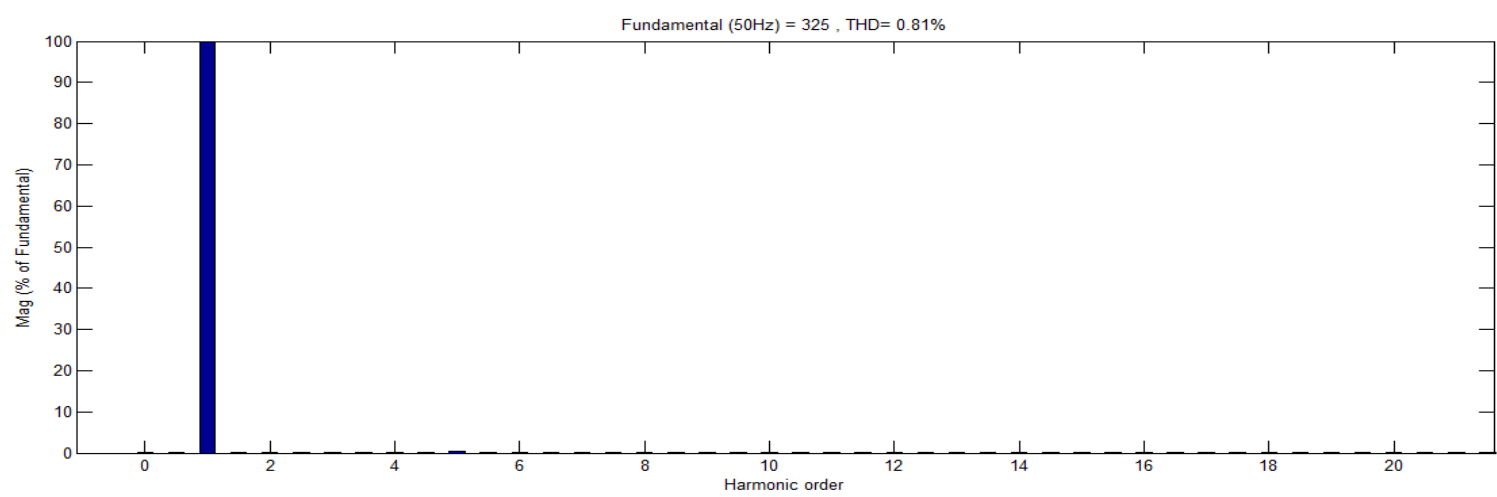

(a)

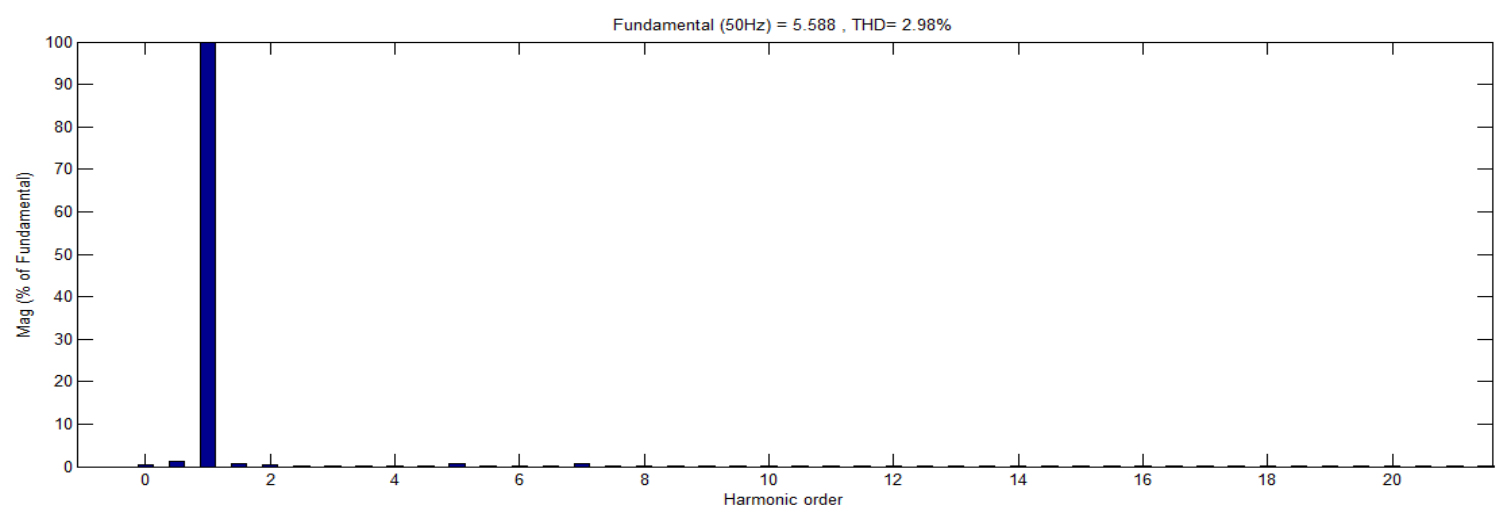

(b) 


\section{Conclusions}

A CSI-based UPQC is proposed in this paper for mitigation of both voltage and current harmonics. It is evident from the results that voltage profile at point of common coupling (Load Voltage) has improved significantly (THD of $0.72 \%$ ) while THD of source voltage is still $6.87 \%$. As the voltage at point of common coupling is sinusoidal, any load can be connected at the PCC. Also source current has become sinusoidal (THD of $2.30 \%$ ). Furthermore the power factor on source side is nearly unity and thus CSI-based UPQC can be used with high efficiency even when load power is low. In case of step load variation of R,it is shown that the load voltage and source current are having THD less than $5 \%$ (THD of load voltage is $1.00 \%$ and that of source current is $1.98 \%$ ), also in case of step variation of R-L load the CSI-based UPQC is working perfectly (THD of load voltage is $1.06 \%$ and that of source current is $1.99 \%$ ) and at last a filter capacitor is attached at load teminals and the operation of CSI-based UPQC is found to be perfect (THD of load voltage is $0.81 \%$ and that of source current is $2.98 \%$ ). Thus it can be concluded that UPQC is a $\mathrm{n}$ ultimate device for removal of both voltage and current harmonics in different load scenarios.

Also one more advantage is that open loop current control is possible with CSI-based UPQC. The continuous development of technology will throw new challenges and will provide new opportunities which will lead to further improvement of CSI-based UPQC technology.

\section{References}

Akagi, H. and Fujita, H. (1995) 'A new power line conditional for harmonic compensation in power systems', IEEE Trans. Power Del., July, Vol. 10, No. 3, pp.1570-1575.

Akagi, H., Hiiokazu, W.E. and Maiuicio, A. (2007) Instantaneous Power Theory and Applications to Power Conditioning, IEEE Press, Hoes Lane, Piscataway, NJ.

Antonio, M-M. (2007) Power Quality: Mitigation Technologies in a Distributed Environment, Springer-Verlag limited, London.

Aredes, M. (1995) 'A combined series and shunt active power filter', in Proc. IEEE/KTH Stockholm Power Tech Conf., Stockholm Sweden, June, pp.18-22.

Balbo, N. and Malesani, L. (1993) 'Hybrid active filter for parallel harmonic compensation', European Power Electronics Conference, Brighton, pp.133-138, August.

Benchaita, L., Saadate, S. and Salem, A. (1999) 'A comparison of voltage source and current source shunt active filter by simulation and experimentation', IEEE Transactions on Power Systems, Vol. 14, No. 2, pp.642-647, May.

Bollen, M.H.J. (2000) Understanding Power Quality Problems Voltage Sags and Interruptions, IEEE Press, Hoes Lane, Piscataway, NJ.

Chen, Y., Zha, X. and Wang, J. (2000) 'Unified Power Quality Conditioner (UPQC): The theory, modeling and application', in Proc. International Conference on Power System Technology Power Con, Vol. 3, pp.1329-1333.
Dugan, R. C., McGranaghan, M.F. and Beaty, H.W. (2006) Electric Power Systems Quality, 2nd ed., McGraw Hill, New York.

Dugan, R.C., Granaghan M.F., Santoso S., Beaty H.W (2004) Electrical Power Systems Quality, 2nd ed., McGraw Hill, India.

Eldin Bahr, S.M., Rao Rama, S.K., Rosdiazli, I. and Perumal, N. (2012) 'Cascade multi-level converter based generalized unified power quality conditioner', 4th International Conference on Intelligent and Advanced Systems (ICIAS), 13013419, September.

Fujita, H. and Akagi, H. (1998) 'Unified power quality conditioner: the integration of series and shunt active filter', IEEE Trans. Power Electronics, Vol. 13, No. 2, pp.315-322.

Grovac, K.V., Alfred, R., Rufer, A. and Knezevic, J. (2001) 'Unified power quality conditioner based on current source converter topology', EPE 2001 - Graz, pp.1-9.

Hagh, M.T. and Sabahi, M. (2016) 'A single phase unified power quality conditioner', in IEEE International Conference in Power System Technology (POWERCON), September.

Hayashi, Y., Sato, N. and Takahashi, K. (1997) 'A novel control of a current source active filter for AC power system harmonic compensation', IEEE Transactions on Industry Application, Vol. 27, No. 2, pp.380-385, March/April.

Horn, A., Pittorino, L.A. and Enslin, J.H.R. (1996) 'Evaluation of active power filter algorithms under non-sinusoidal and unbalanced conditions', in Proc. International Conference on Quality of Power (ICHQP), pp.217-224.

IEEE Std. 1159-1995, Recommended Practice for Monitoring Electric Power Quality.

Khadkikar, V., Agarwa, P., Chandra, A., Bany, O.A. and Nguyen, T.D. (2004) 'A simple new control technique for unified power quality conditioner (UPQC)', 11th International Conference on Harmonies and Quality of Power, Lake Placid, New York, USA, pp.289-293, September.

Salo, M. and Tuusa, H. (2005a) 'A new control system with a control delay compensation for a current-source active power filter', IEEE Transactions on Industrial Electronics, December, Vol. 52, No. 6, pp.1616-1624.

Salo, M. and Tuusa, H. (2005b) 'Comparison of voltage-source and current-source shunt active power filters', IEEE 36th Annual PES Conference (PESCON), Recife, Brazil, pp.2571-2577, June.

Singh, B., Al-haddad, K. and Chandra, A. (1999) 'A review of active power filters for power quality improvement', IEEE Trans On Industrial Electronics, October, Vol. 45, No. 5, pp.960-071.

Syamnaresh, G. and Rajesh, G. (2012) 'Shunt active power filter as front end converters for DC loads', in Proc. 5th India International Conference in Power Electronics, 978-1-46730934-9/12, December.

Vaidirajacharya, K., Pramod, A. and Gupta, H.O. (2007) 'A simple control strategy for unified power quality conditioner using current source inverter', 8th International Power Engineering Conference - IPEC2007, Singapore, December.

Valsala, G.L. and Padma Suresh, L. (2013) 'Novel unified power quality conditioning system for power quality improvement in a nonlinear load', International Conference on Circuits Power and Computing Technologies (ICCPT) 
Venkatesh, C. and Elano, K.M. (2013) 'Improvement of power quality using a hybrid UPQC in renewable energy', International conference on renewable energy and sustainable energy, ICRESE, pp.166-169, October.

Yogesh, P.S., Dharme, A.A. and Talange, B.D. (2014) 'A three phase shunt active power filter based on instantaneous reactive power theory', Annual IEEE India Conference (INDICON), December.
Yunus, H.L. and Bass, R.M. (1996) 'Comparison of VSI and CSI topologies for single phase active power filter', IEEE PESC, pp.1892-1899. 